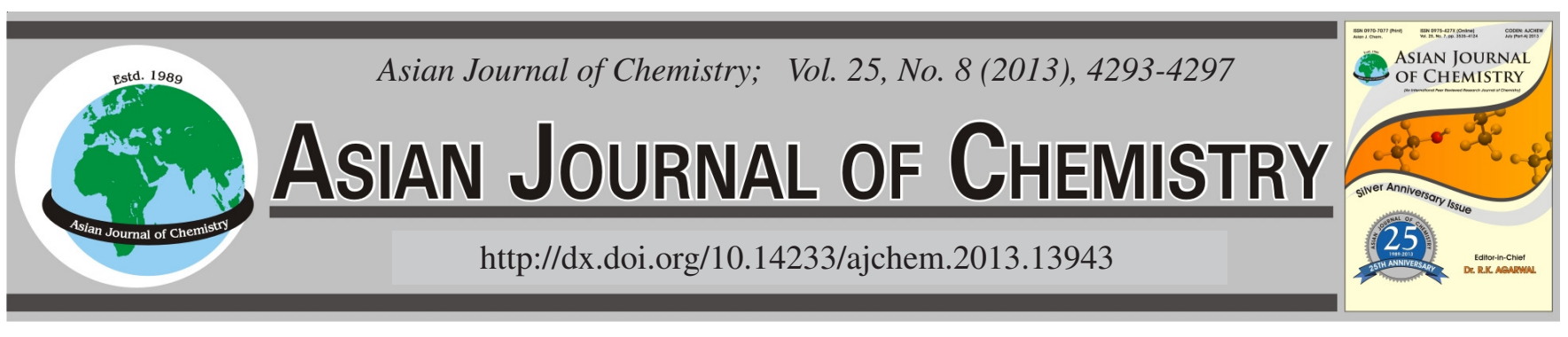

\title{
Anti-oxidative and Anti-inflammatory Effects of Flavonoids from the Silk of Zea mays Linn
}

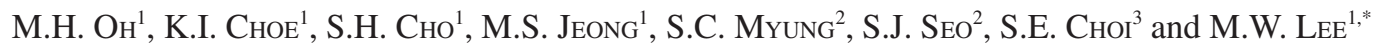

${ }^{1}$ College of Pharmacy, Chung Ang University, Seoul 156-756, South Korea

${ }^{2}$ College of Medicine, Chung Ang University, Seoul 156-756, South Korea

${ }^{3}$ Department of Cosmetology Science, Nambu University, Gwangju City 506-706, South Korea

*Corresponding author: Fax: +82 2 8229778; Tel: +82 2 8205602; E-mail: mwlee@cau.ac.kr

\begin{abstract}
Activity-guided isolation of the silk of Zea mays Linn (ZMS) yielded three flavonoids, chrysoeriol-6-C- $\beta$-boivinopyranosyl-7-O- $\beta$ glucopyranoside (1), chrysoeriol (2) and luteolin (3). Anti-oxidative activity was measured using the 2,2-diphenyl-1-picryl-hydrazyl and superoxide dismutase-like superoxide anion (generated by xanthine oxidase/hypoxanthine) scavenging assays. Anti-inflammatory activity was confined by quantifying the protein and mRNA levels of inducible nitric oxide synthase and cyclooxygenase-2 in lipopolysaccharidestimulated $\mathrm{HaCaT}$ cells using western blotting and real-time polymerase chain reaction. The results showed that luteolin 3 exhibited potent 2,2-diphenyl-1-picryl-hydrazyl $\left(\mathrm{IC}_{50}=18.31 \pm 1.29 \mu \mathrm{M}\right)$ and superoxide dismutase-like superoxide anion scavenging activity $\left(\mathrm{IC}_{50}=1.47 \pm 0.14 \mu \mathrm{M}\right)$ and dose-dependently inhibited the protein expression of inducible nitric oxide synthase and cyclooxygenase-2 as well as their mRNA levels.
\end{abstract}

Key Words: Zea mays Linn, Flavonoid, Anti-oxidative, Anti-inflammatory, Inducible nitric oxide synthase, Cyclooxygenase-2.

\section{INTRODUCTION}

Reactive oxygen species such as superoxide anion, hydroxyl radical and peroxynitrite have been reported to play a critical role in the process of inflammation in various tissues. In skin, reactive oxygen species can be produced by chemical ionization, UV radiation and enzymatically by polymorphonuclear leukocytes that infiltrate the sites of infection ${ }^{1}$. Excessive reactive oxygen species cause extensive damage to DNA, proteins and lipids and have been reported to be pro-inflammatory mediators ${ }^{2}$.

Inducible nitric oxide synthase and cyclooxygenase- 2 are known to be key enzymes in inflammation and oxidative stress $^{3}$. The inducible nitric oxide synthase produces a highly reactive nitrogen radical $^{4}$ (nitric oxide) and cyclooxygenase2 produces prostaglandins that contribute to the pain of inflammation ${ }^{5}$. These two enzymes, which are related to pathological conditions of inflammation, are highly induced by pro-inflammatory cytokines, such as interferon $\gamma($ IFN- $\gamma)$, tumor necrosis factor $\alpha(\mathrm{TNF}-\alpha)$ and interleukin $1 \beta$ (IL-1 $\beta)^{6}$. Thus, the inhibitory activities of these proteins and their mRNAs have proved useful in a variety cell culture studies and animal inflammatory models ${ }^{7}$.

Zea mays Linn (ZMS) has been used as oriental traditional medicine for the treatment of dysuria, uricosuria, edema, cystitis, gout, kidney stones and nephritis ${ }^{8,9}$. Several flavonoids such as chrysoeriol 6-C- $\beta$-fucopyranoside, $2 "-O-\beta$-Lrhamnosyl-6-C-3"-deoxyglucosyl-3'-methoxyluteolin and maysin have been isolated from Zea mays Linn ${ }^{10,11}$. Antiglycation activity and insecticide effects of Zea mays Linn, have been reported ${ }^{12}$. Furthermore, anti-oxidant activity and anti-inflammatory effects of Zea mays Linn extract have also been reported ${ }^{13,14}$.

As part of our on-going screening program to search for new anti-oxidative and anti-inflammatory natural products ${ }^{15}$, we examined the silk of Zea mays Linn (ZMS) for DPPH and SOD-like superoxide anion (generated by xanthine oxidase/ hypoxanthine) scavenging activities and inhibition of the expression of inducible nitric oxide synthase and cyclooxygenase-2.

\section{EXPERIMENTAL}

Thin layer chromatography (TLC) was carried out using pre-coated silica gel $60 \mathrm{~F}_{254}$ plates (Merck, Darmstadt, Germany) and chloroform-methanol-water (80:20:2, 70:30:4 volume ratio). The spots were detected using UV $(254 \mathrm{~nm})$ and by spraying with $\mathrm{FeCl}_{3}$ and $10 \% \mathrm{H}_{2} \mathrm{SO}_{4}$, followed by heating. The stationary phases for the column chromatographic isolation were performed on a Sephadex LH-20 column (25-10 $\mu \mathrm{m}$, Pharmacia), a MCI-gel CHP 20P column (75-150 $\mu \mathrm{m}$, Mitsubishi) and an YMC-gel ODS-A column (230-70 and 500400 mesh, YMC Co.). Compounds were identified by ${ }^{1} \mathrm{H}$ - and 
${ }^{13}$ C NMR (Varian Gemini 2000, USA or Brucker Amx-500) and by mass spectrometry (MS) (API 3000 triple quadrupole mass spectrometry, Canada) and were characterized by comparisons with literature values.

In this study, we used Lot \#2008042500210001 of Zea mays Linn (hot water extract), which was supplied by Kwang Dong Pharmaceutical Co. Ltd., in September 2008. The hot water extracts were the "tea of the silk of Zea mays Linn" (beverage goods of Kwang Dong Pharmaceutical Co. Ltd).

Extraction and isolation: The hot water extracts (Lot \#2008042500210001) of Zea mays Linn were prepared with decompression filtration. The filtrate was then concentrated $(627 \mathrm{~g})$ and solvent fractionation was performed with ethyl acetate, butyl alcohol and water. The ethyl acetate fraction $(62 \mathrm{~g})$, which showed anti-oxidative activity with an $\mathrm{IC}_{50}$ value of $310.88 \pm 1.39 \mu \mathrm{g} / \mathrm{mL}$ compared with the positive control, $\mathrm{L}$-ascorbic acid $\left(\mathrm{IC}_{50}=14.75 \pm 3.87 \mu \mathrm{g} / \mathrm{mL}\right.$ ) (data not shown), was applied to a Sephadex LH-20 column (25-100 $\mu \mathrm{m}, 2000 \mathrm{~g}$, $10 \times 90 \mathrm{~cm})($ Pharmacia, Uppsala, Sweden) and eluted with an $\mathrm{H}_{2} \mathrm{O}-\mathrm{MeOH}$ gradient to yield seven sub-fractions. Sub-fractions 3 and 4 showed anti-oxidative activity with $\mathrm{IC}_{50}$ values of 51.22 $\pm 2.36 \mu \mathrm{g} / \mathrm{mL}$ and $54.82 \pm 3.47 \mu \mathrm{g} / \mathrm{mL}$, respectively, compared with a positive control, L-ascorbic acid $\left(\mathrm{IC}_{50}=13.92 \pm 2.56\right.$ $\mu \mathrm{g} / \mathrm{mL}$ ) (data not shown). Sub-fraction 3 was further separated on a Sephadex LH-20 column $(25-100 \mu \mathrm{m}, 400 \mathrm{~g}, 5 \times 50 \mathrm{~cm})$ (Pharmacia, Uppsala, Sweden) eluted with $60 \% \mathrm{MeOH}$ and a MCI-gel CHP 20P column $(75-150 \mu \mathrm{m}, 200 \mathrm{~g}, 3 \times 25 \mathrm{~cm})$ (Mitsubishi, Tokyo, Japan) eluted with $50 \% \mathrm{MeOH}$. Prepthin layer chromatography (PTLC) was carried out for final purification using pre-coated silica gel $60 \mathrm{~F}_{254}$ glass plates (Merck, Darmstadt, Germany) and chloroform-methanolwater (70:30:4, volume ratio) to yield chrysoeriol 6- $C$ - $\beta$ boivinopyranosyl-7- $O$ - $\beta$-glucopyranoside $(1,75 \mathrm{mg})$. Subfraction 4 was further separated on YMC-gel ODS-A (230/70 mesh, $300 \mathrm{~g}, 5 \times 60 \mathrm{~cm}$ ) (YMC, Japan) and eluted using a $\mathrm{H}_{2} \mathrm{O}-\mathrm{MeOH}$ gradient to yield two sub-fractions (4-1 and 4-2). PTLC was carried out for sub-fraction 4-1 using pre-coated silica gel $60 \mathrm{~F}_{254}$ glass plates (Merck, Darmstadt, Germany) and chloroform-methanol (10:1, volume ratio) to yield chrysoeriol (2, $30 \mathrm{mg})$. Sub-fraction 4-2 was further applied to Sephadex LH-20 column $(150 \mu \mathrm{m}, 100 \mathrm{~g}, 3 \times 30 \mathrm{~cm})$ (Pharmacia, Uppsala, Sweden) and eluted with EtOH- $\mathrm{H}_{2} \mathrm{O}$ gradient to yield luteolin (3, 105mg).

Chrysoeriol 6- $\boldsymbol{C}$ - $\boldsymbol{\beta}$-boivinopyranosyl-7- $\boldsymbol{O}$ - $\boldsymbol{\beta}$-glucopyranoside (1): Yellow amorphous powder; negative LC-MS: $\mathrm{m} / \mathrm{z}$ $594[\mathrm{M}-\mathrm{H}]^{-},{ }^{1} \mathrm{H}$ NMR $\left(600 \mathrm{MHz}, \mathrm{DMSO}-d_{6}+\mathrm{D}_{2} \mathrm{O}\right): \delta 6.87(1 \mathrm{H}$, s, H-8), 6.46 (1H, s, H-3), 7.39 (1H, dd, $J=8.4,1.8$ Hz, H-6'), $7.16\left(1 \mathrm{H}, \mathrm{d}, J=1.8 \mathrm{~Hz}, \mathrm{H}-2^{\prime}\right), 6.32\left(1 \mathrm{H}, \mathrm{d}, J=8.4 \mathrm{~Hz}, \mathrm{H}-5^{\prime}\right)$, 5.24 (1H, dd, $\left.J=13.2,2.4 \mathrm{~Hz}, \mathrm{H}-1^{\prime \prime}\right), 4.77(1 \mathrm{H}, \mathrm{d}, J=7.2 \mathrm{~Hz}$, H-1'"), 3.87 (1H, dd, $J=13.2,6.6 \mathrm{~Hz}, \mathrm{H}-5 "), 3.83$ (1H, d, $J=$ $3.0 \mathrm{~Hz}, \mathrm{H}-3$ "), 3.78 (1H, m, H-6a'"), 3.69 (3H, s, - $\left.\mathrm{OCH}_{3}\right), 3.44$ (2H in total, m, H-6b'" and H-5'"), $3.35(1 \mathrm{H}, \mathrm{t}, J=8.4 \mathrm{~Hz}, \mathrm{H}-$ $2^{\prime \prime \prime)}, 3.30$ (1H, t, $\left.J=9.0 \mathrm{~Hz}, \mathrm{H}-3^{\prime \prime \prime}\right), 3.16(1 \mathrm{H}, \mathrm{d}, J=3.6 \mathrm{~Hz}, \mathrm{H}-$ 4"), 3.12 (1H, t, J = 7.8 Hz, H-4'"), 2.83 (1H, m, H-2a"), 1.21 $(1 \mathrm{H}, \mathrm{d}, J=13.2 \mathrm{~Hz}, \mathrm{H}-2 \mathrm{~b} "), 1.02\left(3 \mathrm{H}, \mathrm{m},-\mathrm{CH}_{3}\right)$.

${ }^{13} \mathrm{C}$ NMR (150 MHz, DMSO- $\left.d_{6}+\mathrm{D}_{2} \mathrm{O}\right)$ : (Table-1).

Chrysoeriol (2): Yellow amorphous powder; negative LC-MS: $m / z, 302[\mathrm{M}-\mathrm{H}]^{-},{ }^{1} \mathrm{H}$ NMR (300 MHz, DMSO- $\left.d_{6}\right): \delta$
$12.0(1 \mathrm{H}, \mathrm{m}, \mathrm{OH}-5), 5.94(1 \mathrm{H}, \mathrm{d}, J=1.8, \mathrm{H}-8), 5.70(1 \mathrm{H}, \mathrm{d}, J$ $=1.8, \mathrm{H}-6), 6.37(1 \mathrm{H}, \mathrm{s}, \mathrm{H}-3), 7.35(1 \mathrm{H}, \mathrm{dd}, J=8.4,1.8 \mathrm{~Hz}$, H-6'), $7.28\left(1 \mathrm{H}, J=1.8, \mathrm{H}-2^{\prime}\right), 6.32\left(1 \mathrm{H}, \mathrm{d}, J=8.4 \mathrm{~Hz}, \mathrm{H}-5^{\prime}\right)$, $3.79\left(3 \mathrm{H}, \mathrm{s},-\mathrm{OCH}_{3}\right) .{ }^{13} \mathrm{C}$ NMR $\left(75 \mathrm{MHz}, \mathrm{DMSO}-d_{6}\right)$ : (Table-1).

Luteolin (3): Yellow amorphous powder; negative LCMS: $m / z, 286[\mathrm{M}-\mathrm{H}]^{-},{ }^{1} \mathrm{H}$ NMR (300 MHz, DMSO- $\left.d_{6}\right): \delta 12.0$ $(1 \mathrm{H}, \mathrm{m}, \mathrm{OH}-5), 6.54(1 \mathrm{H}, \mathrm{d}, J=1.8, \mathrm{H}-8), 6.26(1 \mathrm{H}, \mathrm{d}, J=$ $1.8, \mathrm{H}-6), 6.59$ (1H, s, H-3), 7.45 (1H, dd, $J=8.4,2.4 \mathrm{~Hz}, \mathrm{H}-$ $\left.6^{\prime}\right), 7.50\left(1 \mathrm{H}, \mathrm{d}, J=2.4, \mathrm{H}-2^{\prime}\right), 7.01\left(1 \mathrm{H}, \mathrm{d}, J=8.4 \mathrm{~Hz}, \mathrm{H}-5^{\prime}\right)$. ${ }^{13} \mathrm{C}$ NMR (75 MHz, DMSO- $\left.d_{6}\right)$ : (Table-1).

\begin{tabular}{|c|c|c|c|}
\hline \multicolumn{4}{|c|}{$\begin{array}{c}\text { TABLE-1 } \\
{ }^{13} \mathrm{C}-\mathrm{NMR} \text { DATA OF COMPOUNDS } \mathbf{1 - 3}\end{array}$} \\
\hline Carbon number & ${ }^{\mathrm{a}} \mathbf{1} \delta(\mathrm{ppm})$ & ${ }^{\mathrm{b}} \mathbf{2} \delta(\mathrm{ppm})$ & ${ }^{\mathrm{b}} \mathbf{3} \delta(\mathrm{ppm})$ \\
\hline $\mathrm{C}-2$ & 166.1 & 162.2 & 165.1 \\
\hline C-3 & 99.0 & 100.7 & 104.1 \\
\hline C-4 & 181.1 & 179.8 & 183.0 \\
\hline C-5 & 162.8 & 161.0 & 162.8 \\
\hline C- 6 & 112.6 & 99.6 & 99.6 \\
\hline C-7 & 162.8 & 162.2 & 165.2 \\
\hline C- 8 & 94.4 & 95.9 & 94.7 \\
\hline C-9 & 156.4 & 158.2 & 158.8 \\
\hline C-10 & 105.1 & 100.7 & 105.1 \\
\hline C-1' & 123.5 & 120.8 & 123.4 \\
\hline C-2' & 108.7 & 109.0 & 113.9 \\
\hline C-3' & 151.0 & 149.2 & 146.5 \\
\hline C-4' & 151.0 & 149.2 & 150.2 \\
\hline C-5' & 118.4 & 116.7 & 116.5 \\
\hline C- $6^{\prime}$ & 123.5 & 120.8 & 119.9 \\
\hline$-\mathrm{OCH}_{3}$ & 55.6 & 55.7 & \\
\hline Sugar & (Boivinose) & & \\
\hline C-1" & 65.2 & & \\
\hline C-2" & 30.5 & & \\
\hline C-3" & 67.6 & & \\
\hline C-4" & 69.5 & & \\
\hline C-5" & 70.4 & & \\
\hline 6"-- $\mathrm{CH}_{3}$ & 17.6 & & \\
\hline Sugar & (Glucose) & & \\
\hline C-1"' & 102.6 & & \\
\hline C-2"' & 74.0 & & \\
\hline C-3"' & 77.5 & & \\
\hline C-4"' & 70.4 & & \\
\hline C-5"' & 77.9 & & \\
\hline C-6"' & 62.1 & & \\
\hline
\end{tabular}

DPPH radical scavenging activity: Anti-oxidative activities were measured using 1,1-diphenyl-2-picrylhydrzyl (DPPH) (Sigma, St. Louis, MO) scavenging activities ${ }^{16}$. Briefly, $20 \mu \mathrm{L}$ of the compounds in absolute EtOH was added to $180 \mu \mathrm{L}$ of DPPH solution $(0.1 \mathrm{mM}$, in absolute EtOH). After gentle mixing, the reactions were allowed to stand for $0.5 \mathrm{~h}$ and the optical densities were measured at $492 \mathrm{~nm}$ using an ELISA reader (TECAN, Salzburg, Austria). Free radical scavenging activities were calculated as [(1-(sample O.D./ control O.D. $) \times 100]$ and were expressed as $\mathrm{IC}_{50}$ values, which were defined as the concentrations at which $50 \%$ of DPPH free radicals were scavenged. L-ascorbic acid was used as a positive control.

Superoxide anion scavenging activity: A reaction mixture with a final volume of $632 \mu \mathrm{L}$ was prepared with 50 $\mathrm{mM}$ phosphate buffer ( $\mathrm{pH} 7.5)$ containing EDTA $(0.05 \mathrm{mM})$, hypoxanthine $(0.2 \mathrm{mM}), 63 \mu \mathrm{L}$ nitro-blue tetrazolium $(1 \mathrm{mM})$ 
(Sigma, St. Louis, MO), $63 \mu \mathrm{L}$ of aqueous or ethanolic extract (distilled water for the control) and $63 \mu \mathrm{L}$ of xanthine oxidase (1.2 U/ $\mu \mathrm{L})$ (Sigma, St. Louis, MO) in an eppendorf tube. The xanthine oxidase was added last. For each sample, a blank was carried out. The subsequent rate of nitro-blue tetrazolium reduction was determined on the basis of sequential spectrophotometric determinations of absorbance at $560 \mathrm{~nm}$. The solutions were prepared daily and kept from light. The results are expressed as the percentage inhibition of the nitro-blue tetrazolium reduction with respect to the reaction mixture without sample (buffer only). Superoxide anion scavenging activities were calculated as [(1-(sample O.D.- blank O.D.)/ (control O.D.-blank O.D.) $\times 100$ ] and were expressed as $\mathrm{IC}_{50}$ values, which were defined as the concentrations at which $50 \%$ of nitro-blue tetrazolium/Superoxide anions were scavenged ${ }^{17}$. Allopurinol (Sigma, St. Louis, MO) was used as a positive control.

Cell culture: HaCat human keratinocyte cells were grown in a $75 \mathrm{~cm}^{2}$ flask in a $5 \% \mathrm{CO}_{2}$ atmosphere at $37^{\circ} \mathrm{C}$ in DMEM medium (Sigma, St. Louis, MO) containing $10 \%$ fetal bovine serum, $100 \mathrm{IU} / \mathrm{mL}$ penicillin $\mathrm{G}$ and $100 \mathrm{mg} / \mathrm{mL}$ streptomycin (Gibco BRL, Grand Island, NY).

Western blotting: HaCaT human keratinocyte cells were cultured in 6-well plates and then treated with or without 10 $\mu \mathrm{g} / \mathrm{mL}$ of LPS and samples $(10$ or $100 \mu \mathrm{M})$ for $24 \mathrm{~h}$. Cells were then lyzed in a buffer containing $50 \mathrm{mM}$ tris $-\mathrm{Cl}(\mathrm{pH}$ 8.0), $150 \mathrm{mM} \mathrm{NaCl}, 0.02 \%$ sodium azide, $100 \mu \mathrm{g} / \mathrm{mL}$ phenylmethanesulfonyl fluoride (PMSF), $1 \mu \mathrm{g} / \mathrm{mL}$ aprotinin and $1 \%$ Triton X100 and centrifuged at 12,000 rpm for $0.5 \mathrm{~h}$ at $4{ }^{\circ} \mathrm{C}$. Supernatants were then transferred to new tubes and $30 \mu \mathrm{g}$ of soluble protein was subjected to $15 \%$ sodium dodecyl sulfate polyacrylamide gel electrophoresis (SDS-PAGE) in a sample buffer containing $1 \mathrm{M}$ tris, $50 \%$ glycerol, $10 \%$ SDS, mercaptoethanol and $1 \%$ bromophenol blue. Samples were heated at $95{ }^{\circ} \mathrm{C}$ for $5 \mathrm{~min}$ prior to gel loading. For inducible nitric oxide synthase and cyclooxygenase- 2 detection, separated proteins in gels were transferred to nitrocellulose membranes (Osmonics, Milwaukee, WI) at $0.16 \mathrm{~A}$ for $1 \mathrm{~h}$. Membranes were washed 3 times with Tris-buffered saline Tween-20 (TBS/T), blocked with $5 \%$ skimmed milk for $1 \mathrm{~h}$ at room temperature, incubated overnight at $4{ }^{\circ} \mathrm{C}$ with either goat anti-human inducible nitric oxide synthase, cyclooxygenase2 and $\beta$-actin polyclonal anti-bodies $(1: 1000$ in $5 \%$ bovine serum albumin, Santa Cruz, Delaware, CA) and then washed 3 times with TBS/T. The secondary mouse anti-goat peroxidase conjugated anti-bodies (1:2000 in blocking solution, Santa Cruz, Delaware, CA) were incubated for $1 \mathrm{~h}$ at room temperature. After washing membranes with TBS/T, they were developed with electrochemiluminescence (ECL) solution (Santa Cruz, Delaware, CA) for $3 \mathrm{~min}$ and then exposed to $\mathrm{X}$-ray film (Roche, Indianapolis, IN). The OD values for the channel signals, measured by Gelquant software (MiniBIS Pro, Jerusalem, Israel), were normalized to the OD values for the GAPDH signals; the ratios are expressed as arbitrary units for quantitative comparison.

Reverse transcription polymerase chain reaction: Polymerase chain reaction primers were synthesized using Gene Bank data and a DNA synthesizer (Pharmacia, Björkgatan, Uppsala, Sweden). Their sequences were as follows: inducible nitric oxide synthase (123bp): 5'-ACC AAC TGA CGG GAG ATG AG -3' (sense), 5'- ATA GCG GAT GAG CTG AGC AT-3' (anti-sense) / cyclooxygenase-2 (210bp): 5'-TGA AAC CCA CTC AAA CAC A-3' (sense), 5'-AAC TGA TGC GTG AAG TGC TG-3' (anti-sense) / GAPDH (593bp): 5'-ATT GTT GCC ATC AAT GAC CC-3' (sense), 5'-AGT AGA GGC AGG GAT GAT GT -3' (anti-sense).

HaCaT human keratinocyte cells were treated as described above for Western blotting. Total RNA was isolated from cultured HaCaT cells using TRIzol reagent (Invitrogen, Carlsbad, CA) and cells were added to $1 \mathrm{~mL}$ of TRIzol reagent in a cultured dish. After $5 \mathrm{~min}$ at room temperature, 0.2 $\mathrm{mL}$ of chloroform was added per $1 \mathrm{~mL}$ of TRIzol reagent, tubes were shaken vigorously by hand for $15 \mathrm{sec}$ and then incubated at $15^{\circ} \mathrm{C}$ to $30^{\circ} \mathrm{C}$ for $3 \mathrm{~min}$. Mixtures were centrifuged at $12,000 \mathrm{rpm}$ for $15 \mathrm{~min}$ at $4^{\circ} \mathrm{C}$, after which upper aqueous phases were transferred to fresh tubes and same amounts of 2-propanol were added. Mixtures were then incubated at $4{ }^{\circ} \mathrm{C}$ for $15 \mathrm{~min}$ and centrifuged at $12,000 \mathrm{rpm}$ for $15 \mathrm{~min}$ at $4{ }^{\circ} \mathrm{C}$. The supernatant was removed and then RNA pellet was washed in $500 \mu \mathrm{L}$ of $70 \%$ ethanol with $12,000 \mathrm{rpm}$ at $4{ }^{\circ} \mathrm{C}$ for $5 \mathrm{~min}$. The purified RNA samples obtained were dissolved in $30 \mu \mathrm{L}$ of diethyl pyrocarbonate-distilled water (DEPC-DW) and $3 \mu \mathrm{g}$ aliquots of total cellular RNA was reverse-transcribed at $42^{\circ} \mathrm{C}$ for $0.5 \mathrm{~h}$ in $20 \mu \mathrm{L}$ volumes containing $1 \mu \mathrm{L}$ reverse transcriptase (Takara, Shiga, Japan), 10X buffer $2 \mu \mathrm{L}, 10 \mathrm{mM}$ dNTP $2 \mu \mathrm{L}$ (dNTP mix), oligo dT primer $1 \mu \mathrm{L}$, RNase inhibitor $0.5 \mu \mathrm{L}$ and $25 \mathrm{mM} \mathrm{MgCl}_{2} 4 \mu \mathrm{L}$. cDNA samples $(2 \mu \mathrm{L})$ obtained by RT-PCR were amplified by PCR in a $25 \mu \mathrm{L}$-vessel containing 10X buffer $2.5 \mu \mathrm{L}, 25 \mathrm{mM} \mathrm{MgCl}_{2} 2.5 \mu \mathrm{L}$ and $10 \mathrm{pmol} 0.75 \mu \mathrm{L}$ primer. Thermal cycle profiles were as follows $94^{\circ} \mathrm{C}$ for $5 \mathrm{~min}$ : 35 cycles of $94^{\circ} \mathrm{C}$ for $1 \mathrm{~min}, 59^{\circ} \mathrm{C}$ for $1 \mathrm{~min}, 72^{\circ} \mathrm{C}$ for $1 \mathrm{~min}$ : final extension step of $72^{\circ} \mathrm{C}$ for $10 \mathrm{~min}$. A densitometer was used for quantitative analysis of the PCR products of inducible nitric oxide synthase, cyclooxygenase- 2 and GAPDH on DIG chemiluminescent film (volume of inducible nitric oxide synthase, cyclooxygenase-2/volume of GAPDH).

Statistical analysis: All data are expressed as means \pm $\mathrm{SD}$. Analysis was performed by one-way analysis of variance (ANOVA) followed by the Student-Newman-Keuls (S-N-K) test. Results were considered significantly different when $\mathrm{p}$ values were less than 0.05 . Values bearing different superscripts indicate significant differences.

\section{RESULTS AND DISCUSSION}

Activity guided isolation of the hot water extract of Zea mays Linn afforded three flavonoid derivatives (1-3). Compounds (1-3) were identified as chrysoeriol-6- $C$ - $\beta$-boivino pyranosyl-7-O- $\beta$-glucopyranoside ${ }^{18}$, chrysoeriol $^{19}$ and luteolin ${ }^{20}$, respectively, by comparing their spectral (MS, NMR) data with literature values (Fig. 1).

Anti-oxidative activities of compounds (1-3) were evaluated by determining their DPPH and SOD-like superoxide anion scavenging activity. DPPH radicals readily accept hydrogen due to the unstable nature of the nitrogen, thus anti-oxidative activity can be measured by quantifying the loss of a violet colour when DPPH accepts hydrogen of an anti-oxidant ${ }^{16}$. And, SOD-like superoxide anion scavenging activity was determined by the nitro-blue tetrazolium (NBT) reduction method. In this 
method, superoxide reduces the yellow dye $\left(\mathrm{NBT}^{2+}\right)$ to produce blue formazan. Anti-oxidants are able to inhibit the purple nitro-blue tetrazolium formation ${ }^{17}$. Among these compounds, compound 3 exhibited a potent DPPH free radical scavenging activity with an $\mathrm{IC}_{50}$ value of $13.85 \pm 0.23 \mu \mathrm{M}$, compared with the positive control, $\mathrm{L}$-ascorbic acid $\left(\mathrm{IC}_{50}=18.31 \pm 1.29 \mu \mathrm{M}\right)$ (Table-2). Compound $\mathbf{3}$ also exhibited potent SOD-like superoxide anion scavenging activity with an $\mathrm{IC}_{50}$ value of $1.64 \pm 0.07 \mu \mathrm{M}$, compared with the positive control, allopurinol $\left(\mathrm{IC}_{50}=1.47 \pm 0.14 \mu \mathrm{M}\right)$ (Table-2). These anti-oxidative activities might be due to the ortho-dihydroxy-phenolic moiety, which enables a hydrogen atom to be donated to an active free radical $^{21}$

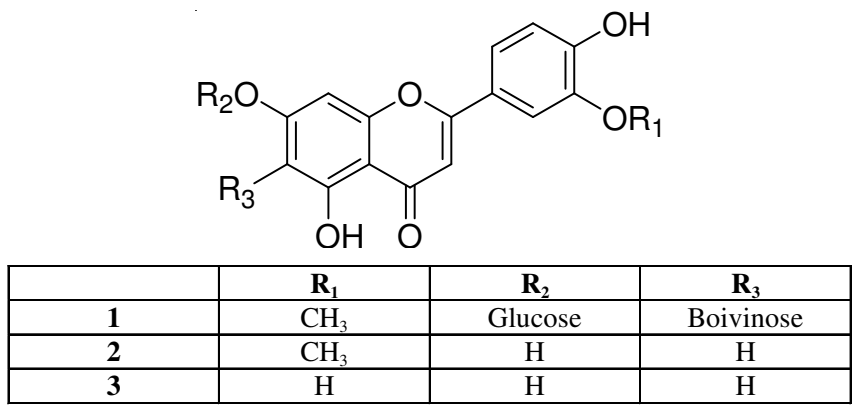

Fig. 1. Chemical structures of compounds $\mathbf{1 - 3}$ isolated from Zea mays Linn

\begin{tabular}{|c|c|c|}
\hline \multicolumn{3}{|c|}{$\begin{array}{c}\text { TABLE-2 } \\
\text { DPPH RADICAL SCAVENGING ACTIVITIES AND } \\
\text { SUPEROXIDE ANION SCAVENGING ACTIVITIES BY } \\
\text { COMPOUNDS 1-3. VALUES REPRESENT MEANS } \pm \text { SD OF } \\
\text { THREE DETERMINATIONS. VALUES BEARING DIFFERENT } \\
\text { SUPERSCRIPTS IN THE SAME COLUMNS ARE } \\
\text { SIGNIFICANTLY DIFFERENT }(\mathrm{p}<0.05)\end{array}$} \\
\hline Compounds & $\begin{array}{c}\mathrm{DPPH} \text { radical } \\
\text { scavenging activity } \\
\mathrm{IC}_{50}(\mu \mathrm{M})\end{array}$ & $\begin{array}{c}\text { Superoxide anion } \\
\text { scavenging activity } \\
\mathrm{IC}_{50}(\mu \mathrm{M})\end{array}$ \\
\hline 1 & $100<<^{a}$ & $100<<^{a}$ \\
\hline 2 & $100<{ }^{a}$ & $4.99 \pm 0.06^{b}$ \\
\hline 3 & $13.85 \pm 0.23^{b}$ & $1.64 \pm 0.07^{b}$ \\
\hline L-Ascorbic acid & $18.31 \pm 1.29^{b}$ & \\
\hline Allopurinol & & $1.47 \pm 0.14^{b}$ \\
\hline
\end{tabular}

The NO production is related to induction of cyclooxygenase- 2 and inducible nitric oxide synthase expression in various inflammatory diseases. Therefore, in order to elucidate the mechanism responsible for the expressions, inducible nitric oxide synthase, cyclooxygenase- 2 proteins and its mRNA were evaluated to prove the anti-inflammatory activities of the compounds (1-3) by western blotting and RT-PCR, respectively. L-ascorbic acid, which is known to inhibit expressions of inducible nitric oxide synthase and cyclooxygenase-2, was used as a positive control ${ }^{22,23}$.

The results showed that luteolin (3) inhibited the expressions of inducible nitric oxide synthase and cyclooxygenase2 proteins and mRNAs. Among the compounds, luteolin (3), which is a flavonol, has a double bond at position C2-C3 of the $\mathrm{C}$ ring with a ketone-function at position 4 , along with $\mathrm{OH}$ groups at positions 3 ' and 4' of the B ring (Fig. 1), which have been related to the inhibition of LPS-stimulated TNF- $\alpha$ release, inhibited the expressions of inducible nitric oxide synthase and cyclooxygenase- 2 proteins and its mRNAs (Figs.
2 and 3$)^{22,24}$. Furthermore, the results showed that aglycone types (2-3) have more potent suppressive effects on inducible nitric oxide synthase and cyclooxygenase- 2 than glycoside type (1) (Figs. 2 and 3) and these compounds (2-3) might play important roles in the anti-inflammatory effects of Zea mays Linn.

\section{Conclusion}

Three flavonoids, chrysoeriol-6- $C$ - $\beta$-boivinopyranosyl-7$O$ - $\beta$-glucopyranoside (1), chrysoeriol (2) and luteolin (3) were isolated from Zea mays Linn. These flavonoid (1-3) showed inhibitory effects against expressions of inducible nitric oxide synthase and cyclooxygenase- 2 proteins and mRNAs., Also, 3 which possess a ortho-dihydroxy-phenolic moiety, exhibited
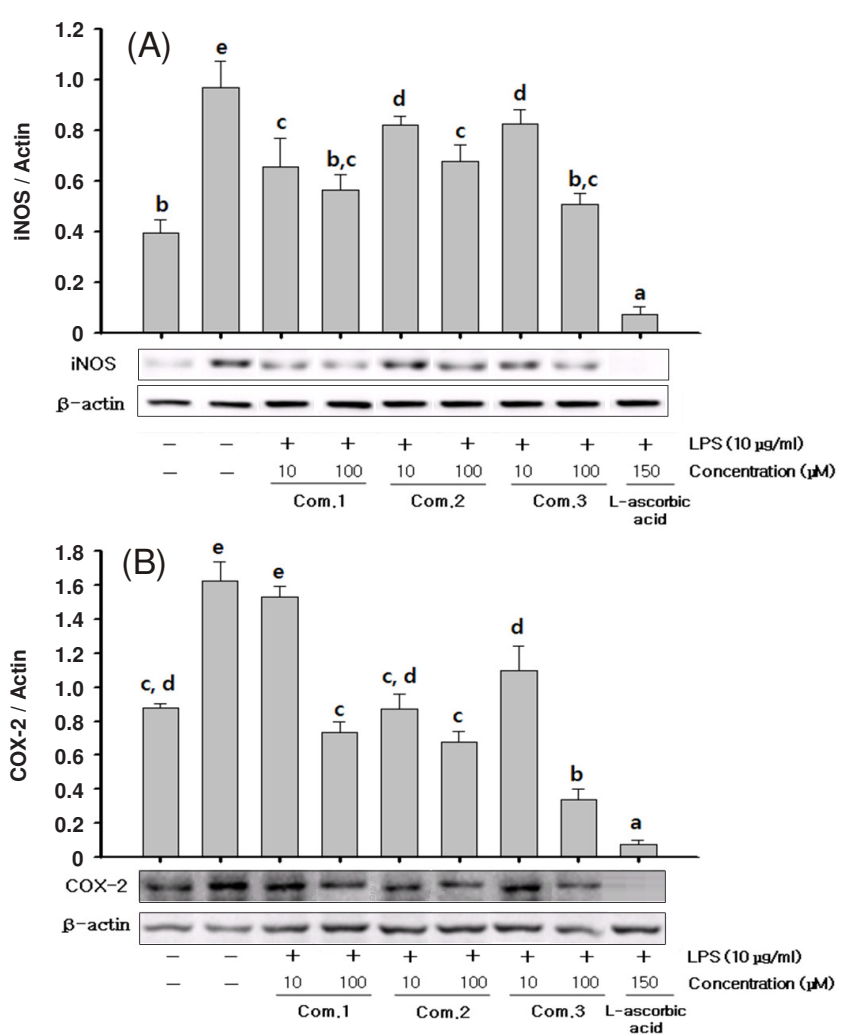

Fig. 2. Effects of compounds $\mathbf{1 - 3}$ on the expressions of iNOS and COX-2 proteins in LPS-induced HaCaT cells. HaCaT cells were cultured in the presence of the indicated compounds for $24 \mathrm{~h}$. The expressions of iNOS (A) and COX-2 (B) were quantified by western blotting. Results are expressed as means \pm SD for triplicate results. Values bearing different superscripts in the same columns are significantly different $(\mathrm{p}<0.05)$

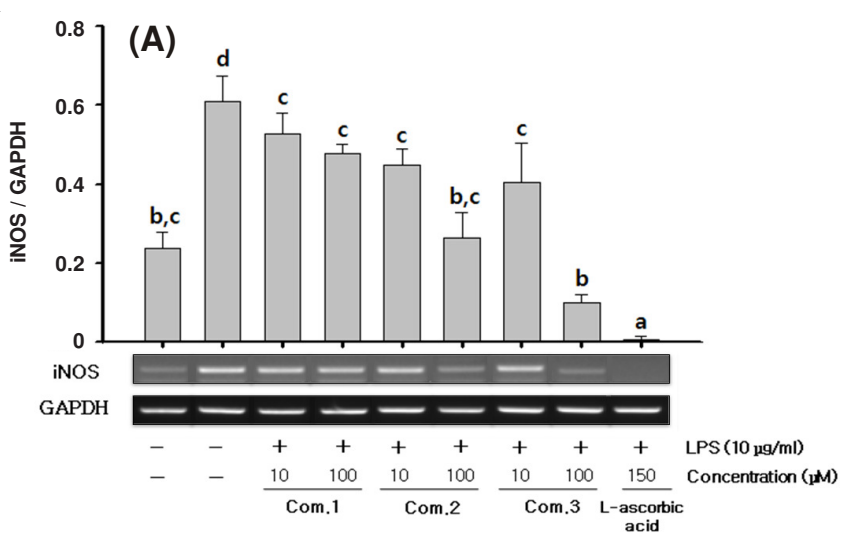




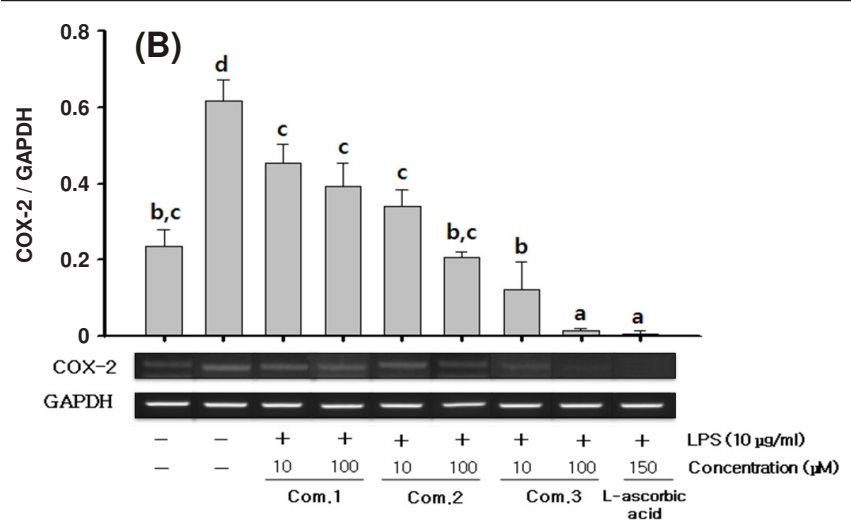

Fig. 3. Effects of compounds $\mathbf{1 - 3}$ on the expressions of iNOS and COX-2 mRNA in LPS-treated $\mathrm{HaCaT}$ cells. HaCaT cells were cultured with the indicated samples for $24 \mathrm{~h}$ and then the expressions of iNOS (A) and COX-2 (B) mRNA were quantified by RT-PCR. Results are expressed as means \pm SD for triplicate results. Values bearing different superscripts in the same columns are significantly different $(\mathrm{p}<0.05)$

potent DPPH radical and SOD-like superoxide anion scavenging activity. Thus, Zea mays Linn and the active compound $\mathbf{3}$ could potentially be developed as anti-oxidative, antiinflammatory ingredients.

\section{ACKNOWLEDGEMENTS}

This research was supported by the Chung-Ang University Research Scholarship Grants in 2011.

\section{REFERENCES}

1. E.M. Choi and J.K. Hwang, Fitoterapia, 75, 557 (2004).

2. H.Y. Joo and K.T. Lim, Environ. Toxicol. Pharmacol., 27, 247 (2009).

3. Y.N. Li, Y.L. Wu, Z.H. Jia and J.S. Qi, J. Ethnopharmacol., 119, 305 (2008).
4. J.L. Wallace, Mem. Inst. Oswaldo Cruz., 100, 5 (2005).

5. J.R. Vane, J.A. Mitchell, I. Appleton, A.T. Linson, D. Bishop-Bailey, J. Croxtall and D.A. Willoughby, Proc. Nat. Acad. Sci. USA, 91, 2046 (1994).

6. T. Csont, S. Viappiani, J. Sawicka, S. Slee, J.Y. Altarejos, I. BatinicHaberle and R. Schulz, J. Mol. Cell Cardiol., 39, 833 (2005).

7. T.A. Swierkosz, J.A. Mitchell, T.D. Warner, R.M. Botting and J.R. Vane, Br. J. Pharmacol., 114, 1335 (1995).

8. H.W. Lim, S.J. Kang, M. Park, J.H. Yoon, B.H. Han, S.E. Choi and M.W. Lee, Nat. Prod. Sci., 12, 221 (2006).

9. M.A. Ebrahimzadeh, F. Pourmorad and S. Hafezi, Turk. J. Biol., 32, 43 (2008).

10. R. Suzuki, Y. Okada and T. Okuyama, J. Nat. Prod., 66, 564 (2003).

11. S.C. Ren, Z.L. Liu and X.L. Ding, J. Med. Plant Res., 3, 1009 (2009).

12. Z. Maksimovíc, D. Malencíc and N. Kovacevíc, Bioresour. Technol., 96, 873 (2005).

13. A. El-Ghorab, K.F. El-Massry and T. Shibamoto, J. Agric. Food Chem., 55, 9124 (2007).

14. Z.A. Maksimovic and N. Kovacevic, Fitoterapia, 74, 144 (2003).

15. K.A. Kim, H.H. Shin, S.K. Choi and H.S. Choi, Biosci. Biotech. Biochem., 69, 1848 (2005).

16. T. Hatano, R. Edamatsu, M. Hiramatsu, A. Mori, Y. Fujita, T. Yasuhara, T. Yoshida and T. Okuda, Chem. Pharm. Bull., 37, 3005 (1989).

17. I. Parejo, F. Viladomat, J. Bastida, A. Rosas-Romero, N. Flerlage, J. Burillo and C. Codina, J. Agric. Food Chem., 50, 6882 (2002).

18. R. Suzuki, Y. Okada and T. Okuyama, Chem. Pharm. Bull., 51, 1186 (2003).

19. A.S. Awaad, D.J. Maitland and G.A. Soliman, Med. Chem. Lett., 16, 4624 (2006).

20. M. Miyazawa and M. Hisama, Biosci. Biotech. Biochem., 67, 2091 (2003).

21. J. Han, X. Weng and K. Bi, Food Chem., 106, 2 (2008).

22. F. Wu, K. Tyml and J.X. Wilson, FEBS Lett., 520, 122 (2002).

23. S.S. Man, K. Kim, E.R. Hahm, S.J. Lee, Y.J. Surh, H.K. Park, W.S. Kim, C.W. Jung, M.H. Lee, K. Park, J.H. Yang, S.S. Yoon, N.H. Riordan, H.D. Riordan, B.F. KimLer, C.H. Park, J.H. Lee and S. Park, J. Cell Biochem., 93, 257 (2004).

24. S. Hougee, A. Sanders, J. Faber, Y.M.F. Graus, W.B. van Den Berg, J. Garssen, H.F. Smit and M.A. Hoijer, Biochem. Pharmacol., 69, 241 (2005) 